\title{
The Effect of Participative Learning Strategy and Interpersonal Communication on Results of Civic Learning Education
}

\author{
$\underline{\text { Robinson Hutagaol }}^{1}$, Abdul Hasan Saragih ${ }^{2}$, Sahat Siagian ${ }^{3}$ \\ ${ }^{1}$ General Functional in Youth and Sports Agency of Sumatera Utara Province, Indonesia \\ 2,3 Departement of Educational Technology, Universitas Negeri Medan, Indonesia \\ Email: rhgaol9@gmail.com
}

\begin{abstract}
The purpose of this study is to determine the differences in civic learning outcomes of students who are taught with participatory group and individual learning strategies, know the differences in civic learning outcomes that have high interpersonal communication and who have low interpersonal communication and know the interactions between learning strategies and interpersonal communication learning outcomes of Civics. To test the hypothesis the learning outcomes used are civic learning outcomes that have high interpersonal communication and learning outcomes that have low interpersonal communication. The statistical test used in this research descriptive statistics presents the statistical data used by ANAVA, the data analyst requirements test, namely the normality test, the lilifors and the Variance homogeneity test with the Bartlett test. The research instrument of civic learning outcomes using a multiple choice test consists of 35 items and has a reliability of 0.761 using the Kuder-Richardson formula (KR-20). For students who have high and low interpersonal communication using interpersonal communication tests using a standard Likert scale. The results of hypothesis testing show that being taught with a participatory group strategy has a higher PKn learning outcome than the individual participatory strategy learning outcomes. This is indicated by the count $=1.20>$ table $=4.02$, at the significance level $a=0.05$. High interpersonal communication higher Civics learning outcomes that have low interpersonal communication. This is indicated by F arithmetic $=48.46>$ table $=4.06$ on Significant level $a=$ 0.05 with $d k=(1.76)$, and the interaction between learning strategies and students' interpersonal communication towards learning outcomes of Civics. This shows the count $=$ $48.46>$ table $=4.06$ at a significant level $a=0.05$.
\end{abstract}

Keywords: participatory learning strategies; interpersonal communication; civic education

\section{Introduction}

Education is part of the intellectual life of the nation as mandated in the 1945 Constitution, likewise in the Law of the Republic of Indonesia No. 20 of 2003 concerning the National Education System which states that the goal of national education is to educate the life of the nation, to develop the potential of students so that they can become people who have faith and are devoted to God Almighty, noble, capable, creative, independent and become citizens of a democratic and responsible country. To that end, the government has sought to develop the education sector in a planned, directed, and gradual manner and integrated with the overall development of the nation's life, both economic, social, cultural, scientific and technological. (Rasien, 2020)

Participatory Teaching and Learning Strategies are learning by actively involving students in planning, implementing and evaluating learning. By borrowing Jarvis (1983, p. 74) put forward a theoretical perspective on learning according to andragogical concepts. While Knowles (1977, p. 9) put forward the history of the use of the term "andragogy which he developed. Knowles is famous for his andragogy theory and is therefore considered the father of andragogy theory even though he was not the first to use the term ". The term andragogy 
as a theoretical term for educational philosophy was used in 1993 by Alexander Kapp of the German People who worked as Granner's school teacher, but later the term disappeared in the circulation of the times. in 1921, the term reappeared Eugene Rosenstock, a teacher at the labor academy at Franfrut, in his report to the academy, he expressed the opinion that adult education requires special teachers, special methods, strategies and philosophies, not educational theories or pedagogy applied to the educational situation for children. For this reason, professional lecturers are needed who can collaborate with students. Only such a lecturer can act as an andragogist for adult education, as a match for a pedagogy for education for children. Since the 1970s the term andragogy is increasingly being used by adult education officers in Europe such as the Netherlands, France and the United Kingdom, even in the Americas such as the United States, Venezuela and Canada, as well as in Asia, namely India (Madras University).

Knowles (1980, p. 9) in his book entitled The Modern Practice of Adult Education, in addition to examining the theoretical perspective of learning for adults, he also examines the theoretical perspective of adult learning, but in this discussion the emphasis is on the theoretical perspective of adult learning. It emphasizes the difference between learning for adults and learning for children in terms of their cognitive development. According to him, there are four main assumptions that distinguish between andragogy and pedagogy, namely: a). Differences in self-concept, adults need more freedom of self-direction. Rich in learning activities. c). Readiness to learn, adults want to study the problem areas that are now faced and are considered relevant.

So far, Civics lecturers assume that the process and content of the subjects are not so important in teaching lecturers to have a single authority, and the most striking is the lack of activities that encourage students to reflect and reflect, participate, to develop critical thinking (Consequently) Civics courses are considered boring because most students must memorize, without any problems faced. Dearing (2000, p. 35) Higher education in participatory students who study and learn to succeed has set a challenging agenda for compulsory, post compulsory and postgraduate education. Higher education in the next century. Each will seek to articulate and further contribute from education to democratic, civilized and inclusive societies.

This volume is a response to challenges positively and imaginatively by combining them using experience, reflection. By looking at the phenomena above, of course it takes an active role and more serious attention by various related parties to be able to improve the learning outcomes of Civics as expected. In this case the lecturer has a very difficult task to overcome the problem in question. Because lecturers have a role in relation to the learning process. This role is to transform knowledge, skills and, participatory, and values to students to encourage participation. According to Gagne (1985, p. 105) there are three functions that lecturers can play in teaching, namely designing, managing, and evaluating teaching.

This opinion is in line with what was stated by Hamalik (1993, p. 35) that operationally there are 5 (five) main variables that play a role in the teaching and learning process, namely teaching objectives, material lessons, teaching strategies, lecturers, students and logistics. All of these components depend on one another. Therefore, professional lecturers are needed namely lecturers who always make preparations, starting from planning learning objectives, organizing material, planning, methods, media, evaluation, and being able to realize what has been planned appropriately. Therefore, it is necessary to conduct an assessment and renewal (innovation) in a learning strategy using participatory. 
Participatory learning strategies need to be carried out with the following procedures: Creating an atmosphere that encourages students to be ready to learn, (2) Helps students organize groups to be ready to learn and teach, (3) Helps students to diagnose. (4) Helping students set learning goals, (5) Helping students design learning experience patterns, (6) Helping students do learning activities, (7) Helping students do a self-evaluation of the learning process and outcomes.

\section{Review of Literatures}

\subsection{The Nature of Participatory Learning Strategies}

Participatory learning strategies include plans, and sets of activities planned to achieve certain goals (Gulo, 2002, p. 23) Stating that "By preparing a learning plan, preparation of learning and tools needed in learning, efforts to achieve learning objectives are more likely to achieved ". A learning program that is held by a lecturer in one face-to-face can be implemented with a variety of strategies such as lectures, group discussions and questions and answers. The overall strategy is for educational media used to describe participatory learning strategies.

Thus it can be concluded that the learning strategy is a basic design for a lecturer on how he brings his learning in class responsibly. Means the learning strategy is one of the learning techniques, namely as a tool to operate what is planned in (Gulo, 2002: 34), saying "that which is owned by lecturers and students, learning resources, learning media, learning materials, class organization, time available and classroom conditions and the environment are elements that also support learning techniques". The experts argue that there are a number of components needed in carrying out a learning which includes: (1) Learning objectives are considered references, learning objectives oriented to the formation of attitudes will certainly not be achieved if learning is oriented towards cognitive dimensions; (2) Lecturers, each lecturer differs in experience, knowledge, ability to present learning, learning style, outlook on life, and insight. This difference results in differences in the learning selection used in the learning program; (3) Students in teaching and learning activities, students have different backgrounds. Like the social environment, cultural environment, learning styles, economic conditions, and the level of intelligence. Each is different for each student. The higher the diversity of the community the greater the difference of this variation in class. This needs to be considered in developing an appropriate learning strategy. (4) Learning material can be distinguished between formal and informal material. Formal material is the content of the lessons contained in official textbooks (textbooks) at school, while informal material is learning materials sourced from the school environment concerned. This component is one input that certainly needs to be considered in the learning strategy. (5) Learning strategy. Surakhaman (1986, p. 23), said that strategy can be interpreted as a way in its function as a tool to achieve a goal. While the notion of learning is the activity of the lecturer guiding and encouraging students to gain experience that is useful for the development of all the potential they have. There are various learning strategies.

\subsection{The Nature of Interpersonal Communication}

The authors commonly define communication as the transfer (transfer) or exchange (exchange) of information (Pace and Faules, 1998: 28). An expert gives varying limits about communication: 1) Communication is the regular transfer of one or several meanings or intentions, 2) Communication is social interaction through messages, or communication is the creation of mutual giving and receiving meaning, and 3) Communication is various (sharing) information ideas or attitudes among people (Mohan, Gregor, and Strano, 1992: 4-5). 
A simple definition of communication is a transfer of meaning / understanding of effective communication that is the sender to the recipient and includes three important parts of effective communication namely the sender, receiver, and the success of sending meaning (Gibson and Hodgetts, 1986: 4). The three important parts are the basic elements that must exist in communication. In his other book it is made clear that the function of communication is; 1) The sender (the sender) must deliver the message accurately and completely, 2) The recipient must understand the message (massage), and 3) The recipient must be willing to act in the manner desired by the sender (Hodgestts and Kuratko, 1988: 254). The three functions in question are the basic elements that must exist in communication.

Based on this theory it is known that readiness to open up has a correlation with interpersonal attractiveness. This is supported by the opinion that the better the interpersonal relationships, the more open the expression of feelings, the more likely to examine feelings in depth, and the more likely to listen attentively (Rachmat, 1998: 120). This will expand our public to this research lecturer interpersonal communication is an action taken by a lecturer in conveying meaningful messages to students through: Familiarization efforts, which include: creating conditions and adjusting themselves, 2) Understanding others, which includes: trust, sympathy, and empathy for others, and 3) Openness includes: accepting other people's opinions and wanting to improve themselves.

\section{Research Methods}

This research will be conducted at the Akper Sarimearl City Foundation, Medan City from March to May 2009 until completion. The timing of the study was adjusted to the educational calendar. Population is the totality of all possible values, arising from the results of quantitative calculations or measurements of certain characteristics of all members of a complete and clear collection, which want to be studied its properties (Sudjana, 1992).

The population in this study were all Semester I (one) students, amounting to three (3) classes in the 2008/2009 school year. The sample is a part of the population chosen representative, meaning that the characteristics of the population are reflected in the sample taken (Sudjana, 1992). From the entire population of 3 classes, a random sampling technique was taken by cluster sampling. Selection of sample classes by lottery and selected as samples is class -A. for the experimental group with Individual Participatory Learning Strategies totalling 55 Students and class B for Group Participatory Learning Strategies totalling 55 Students.

In general, the design of this study uses a $2 \times 2$ block design, through this design the effects of Participatory Learning Strategy and interpersonal communication on the civic learning outcomes can be compared as follows.

Table 1. Factorial Design $2 \times 2$

\begin{tabular}{|c|c|c|}
\hline $\begin{array}{c}\text { Learning strategies } \\
\text { (A) }\end{array}$ & $\begin{array}{c}\text { Participatory } \\
\text { student group } \\
\text { (A1) }\end{array}$ & $\begin{array}{c}\text { Participative individually } \\
\text { college student } \\
\text { (A2) }\end{array}$ \\
\hline Interpersonal Communication (B) & A1B1 & A2B2 \\
\hline High (B1) & A1B2 & A2B2 \\
\hline Low (B2)
\end{tabular}


Information:

A1B1: Groups of students who are treated with high participatory group learning strategies and interpersonal communication.

A2B1: Student groups who are treated with individual participatory learning strategies and high interpersonal communication.

A1B2: Student groups treated with low group participatory learning strategies and interpersonal communication.

A2B2: Groups of students who are treated with individual participatory and low interpersonal communication.

In this study the data were analyzed with ANAVA at a significant level of $5 \%$. For the requirements analysis test, the normality test uses the Lilliefors test, while the homogeneity test uses the Bartlett test from Sudjana (1992). Because there are differences and interactions between variables, the analysis continues with the Seheffe test. The Seheffe test is used because a lot of data in each column and row is not the same.

\section{Discussion}

Research hypotheses were tested by analysis of variance (ANAVA) techniques. For the purposes of the analysis the average scores of each treatment group are presented in Table 1, which is used in determining statistically whether the average score is significant or not. The parent table of Civics Learning Outcomes data is shown in Table 2 below.

Table 2. Summary of Research Results Data

\begin{tabular}{|c|c|c|c|}
\hline \multirow{2}{*}{$\begin{array}{c}\text { Communication } \\
\text { Interpersonal }\end{array}$} & \multicolumn{2}{|c|}{ Participatory Learning } & \multirow[b]{2}{*}{ Total } \\
\hline & Individual & Group & \\
\hline $\operatorname{High}(\mathrm{T})$ & $\begin{array}{l}T_{11}=306 \\
- \\
X 11=25,5 \\
n_{11}=12\end{array}$ & $\begin{array}{l}T_{21}=394 \\
- \\
X 21=26,92 \\
n_{21}=15\end{array}$ & $\begin{array}{l}\mathrm{T} 1=51,77 \\
\mathrm{X} 1=25,93\end{array}$ \\
\hline
\end{tabular}

\begin{tabular}{clll} 
Rendah (R) & $T=245$ & $T_{22}=240$ & $\mathrm{~T}_{1}=42,27$ \\
& $\bar{X}_{12}=22,27$ & $\bar{X}_{22}=20,00$ & $\mathrm{X}_{1}=21,09$ \\
& $n_{12}=11$ & $n_{22}=12$ & \\
Total & $\mathrm{T}_{1}=47,77$ & $\mathrm{~T}_{2}=46,27$ & $\mathrm{~T}_{3}=94,04$ \\
& $\mathrm{X}_{1}=23,96$ & $\mathrm{X}_{2}=23,48$ & $\mathrm{X}_{3}=23,70$ \\
\hline
\end{tabular}

After the master data of the research results are processed with $2 \times 2$ factorial Anava techniques, the results are obtained as shown in Table 3.

Table 3. Summary of Factorial Anava Calculation Results $2 \times 2$

\begin{tabular}{|l|c|c|c|c|c|}
\hline Source of Variation & $\mathrm{JK}$ & $\mathrm{db}$ & $\mathrm{KT}$ & $\mathrm{Fh}$ & $\mathrm{Ft}(5 \%)$ \\
\hline $\begin{array}{l}\text { Line (Communication } \\
\text { Interpersonal = PP }\end{array}$ & 278,16 & 1 & 278,16 & 48,46 & 4,06 \\
\hline $\begin{array}{l}\text { Column (Learning } \\
\text { Participatory = PP) }\end{array}$ & 6,90 & 1 & 6,90 & 1,20 & \\
\hline Interaction Kx PP. & 28,48 & 1 & 28,48 & 4,96 & \\
\hline Inside & 264,12 & 46 & 5,74 & & \\
\hline
\end{tabular}


Differences in the Effect of Individual Participatory Learning Against Student Learning Outcomes of Akper Sari Mutiara Medan City.

The first hypothesis is shaped:

$\begin{array}{llll}\text { Ho } & & P & P T \\ & : & & K \\ \mathrm{Ha} & & P & P T \\ & : & T I & K\end{array}$

With the sentence read:

Ho There is no difference in Civics learning outcomes between students who are taught with individual participatory learning and students who are taught with group participatory learning.

Ha There are differences in Civics learning outcomes between students who are taught with individual participatory learning and students who are taught with participatory group learning.

Based on Table 21 above, for participatory learning a large $\mathrm{Fh}=1,20$. For a $=5 \%$ with $\mathrm{dk}=(1.46)$ percentile value for distribution F obtained F0.05 (1.46) $=4.06$ so that it can it is stated that $\mathrm{Fh}=1.20<\mathrm{Ft}=4.06$. The test results accept $\mathrm{Ho}$ and reject $\mathrm{Ha}$ at a significant level of $5 \%$. From the testing criteria set and rejecting $\mathrm{Ha}$ or in other words there is no difference in Civics learning outcomes between students and group participatory learning.

Differences in the Effect of Interpersonal Communication Against Student Learning Outcomes of Akper Sari Mutiara Medan City.

$\begin{array}{ll}: \text { KRT } & \text { KRR } \\ : \text { KRT } & \text { KRR }\end{array}$

With the sentence read:

Ho: There is no difference in civic learning outcomes between students who have high interpersonal communication and students who have low interpersonal communication.

Ho: There are differences in Civic learning outcomes between students who have communication high interpersonal and students who have interpersonal communication low.

The influence of interpersonal communication in improving learning outcomes Civic can be large $\mathrm{Fh}=48,46$. Testing for $\mathrm{a}=5 \%$ with $\mathrm{dk}=(1.46)$ based on the distribution value percentile table F obtained F0.05 (1.46) = 4, 06 so that it can be stated that $\mathrm{Fh}=48.46>\mathrm{Ft}=$ 4.06 so it can be stated that $\mathrm{Fh}=48.46>4.06$. From the test results reject Ho and accept $\mathrm{Ha}$ in a significant level of $5 \%$. Therefore can say that: "learning outcomes of students who have communication High interpersonal better than the learning outcomes of students who have low interpersonal communication'.

The Interaction of Participatory Learning with Interpersonal Communication in Influencing Learning Outcomes of Civics Students Akper Sari Mutiara Medan.

The third hypothesis is shaped:

Ho $\quad$ : РT $\quad$ RR 0

$\mathrm{Ha} \quad$ : $\mathrm{PT} \quad$ RR 0

With the sentence read:

Ho : There is no interaction between participatory learning and interpersonal communication on student civic learning outcomes 
$\mathrm{Ha}$ : There is an interaction between learning and interpersonal communication learning Civics college student

Based on Table 21 above the interaction between participatory learning and communication interpersonal in influencing learning outcomes obtained large $\mathrm{Fh}=4.96$ for a $=5 \%$ with $\mathrm{dk}=(1.46)$ based on the percentile distribution table $\mathrm{F}$ values obtained F0.05 (1.46) $=4.06$ so it can be stated that $\mathrm{Fh}=4.96>\mathrm{Ft}=4.06$. It can be said that the test results reject $\mathrm{Ho}$ and accept $\mathrm{Ha}$ in a significant level of 0.05 . Thus it can be said that "there is a very significant interaction between participatory learning and interpersonal communication in influencing student civic learning outcomes ". Based on the results of hypothesis testing above can be described the interaction between learning and interpersonal communication in influencing the following civic learning outcomes.

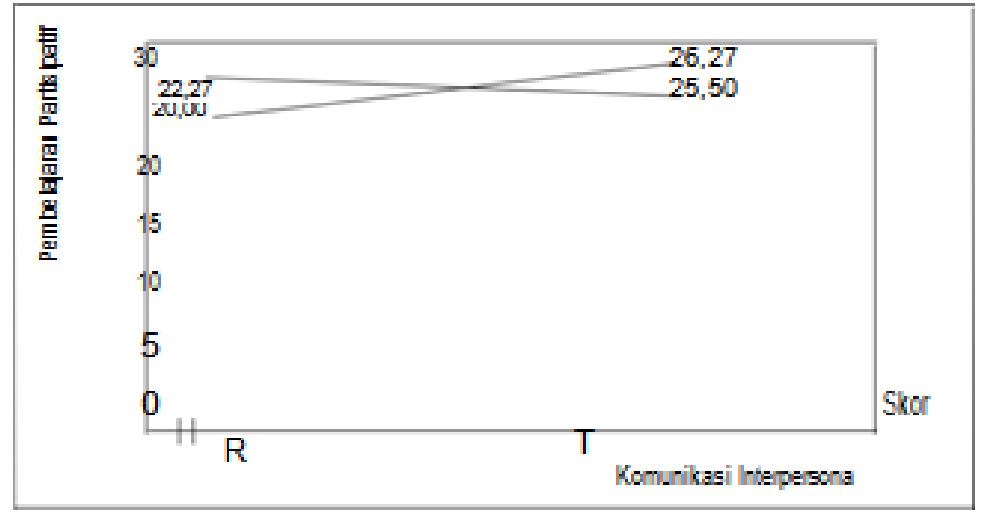

Figure 1. Interactions that Happen Between Participatory Learning and Interpersonal Communication in Influencing Student Learning Outcomes.

Figure 1 The above shows that Civics Learning Outcomes using Group Participatory Learning are higher than students who are taught with Individual Participatory Learning strategies and achieving forms of interaction between Participatory Learning and student communication, where students describe the estimated line of interaction between the two variables. On the abscissa axis of interpersonal communication variables, namely $\mathrm{KIT}=$ high interpersonal communication and KIR = low interpersonal communication, while on the ordinate axis the average score of the Civics learning outcomes variable is in accordance with the treatment of individual participatory learning namely PPI and group participatory learning namely PPK. Group participatory learning is appropriate for improving civic learning outcomes of students who communicate low, whereas individual participatory learning is appropriate for students who communicate high interpersonal.

Table 4. Summary of Results of Continued Tests with Scheffe Test

\begin{tabular}{|c|l|c|c|c|}
\hline No & Average Comparison Group & Fh & Ftab (5\%) & Information \\
\hline 1. & PPIKIT-PPKKIT & 0,91 & 2,79 & $\mathrm{Fh}>\mathrm{Ft}$ \\
2. & PPIKIT-PPIKIR & 3,26 & 2,79 & $\mathrm{Fh}>\mathrm{Ft}$ \\
3. & PPIKIT-PPKKIR & 5,85 & 2,79 & $\mathrm{Fh}>\mathrm{Ft}$ \\
4. & PPKKIT-PPIKIR & 4,44 & 2,79 & $\mathrm{Fh}>\mathrm{Ft}$ \\
5. & PPKKIT-PPKKIR & 7,29 & 2,79 & $\mathrm{Fh}>\mathrm{Ft}$ \\
6. & PPKKIR-PPIKIR & 2,27 & 2,79 & $\mathrm{Fh}>\mathrm{Ft}$ \\
\hline
\end{tabular}

The results of testing the research hypothesis indicate that in general individual participatory learning does not have a different effect on Civics learning outcomes compared to group participatory learning. This may be caused because individual and group participatory 
learning each has advantages and disadvantages. Civic learning outcomes of students taught by participatory learning and interpersonal communication can be explained by instructional theory.

The results of this study indicate that individual participatory learning is not significant, indicating a difference in the average score of the results obtained in the Civics subject in Akper Sari Mutiara, Medan City. Average score of learning taught with individual participatory learning $X_{P T T}=23,96$ slightly different from the average score average Civics learning outcomes with group participatory learning $X_{P T I}=23,48$ or can is said to have the same average learning outcomes. By remembering the support in the previous frame of mind that the average PKn learning outcomes of the students of Akper Sari Mutiara Medan who were taught with individual participatory learning could not be proven, specifically the proofs of the estimation show that individual participatory learning had no effect in increasing the average score of results studying Civics learning in Akper Sari Mutiara Medan.

Teaching management strategies relate to when an appropriate strategy is used in a teaching condition including the application of learning with group participatory learning. To create active students in the learning process, the willingness and skills of lecturers are needed in making decisions that are appropriate to the learning situation created and consider the objectives to be achieved in accordance with existing conditions. Many education experts agree that group participatory learning can help the learning process so that student learning outcomes improve (Thabrany, 1995). There are several advantages gained when implementing participatory group learning, namely (1) reducing boredom and drowsiness especially in studying material that does not attract the attention of students, (2) increasing motivation to learn because students mingle with their friends which at the same time can create a spirit of competition among students in group, allows to ask more questions and get corrections in group friends, (4) raises oral recitation, that is, students can freely express what is on their minds, (5) give rise to associations about events that are easy to remember.

From the results of the study it can be said that participatory learning in this group must be adjusted to the characteristics of the subject matter to be delivered. This means that in learning lecturers must be able to choose what approach is suitable for the material to be delivered. The absence of significant differences in student learning outcomes taught by individual participatory learning and participatory group learning does not mean that this is not good. Participatory group learning is quite effective to use in learning because it can increase the students' ability to discuss and ask one another, ask the lecturer, so that during the activity students are always active.

The results of the research are not so optimal in supporting this theory, it might be due to the inaccurate selection of samples, so that the results of student Civics Education learning with group participatory learning are not much different from student Civics Learning outcomes taught by individual participatory learning. Even so, participatory group learning encourages students' interpersonal communication to work together, but if students are less interested in group work or if in discussion activities merely follow, it will result in decreased learning outcomes. In addition, maybe because of cognitive abilities, such as difficulty transferring knowledge to solve problems or in other words if the lecturer does not act as a facilitator will be ignored as a result of learning outcomes are not good.

In testing the second hypothesis that the null hypothesis is rejected, so this research hypothesis states that the learning outcomes of Civics students who have high communication will be better than students who have low communication. The effect of participatory learning 
on the teaching of Civic Education on efforts to improve student interpersonal communication in this study is quite high. This is understandable, given the opinion of Degeng (1990), stating that learning outcomes are classified into 3 parts, namely: (a) The effectiveness of teaching, (b) The efficiency of teaching, and (c) The attractiveness of teaching.

High or low interpersonal communication of students gives a different effect on the learning outcomes of Civics. Or in other words, groups of students who have high interpersonal communication get different Civics learning outcomes, when compared to groups of students who have low interpersonal communication. Improvement of students' interpersonal communication can be done through efforts related to the development of basic interpersonal communication skills such as fluent, flexible, rational, detailed, curiosity in providing ideas, in addition to exercises directly related to learning.

Exercises for fluency, flexibility and rationality can be pursued through training in imagination, perception, enlightening, seeing possibilities, providing predictions, good-badinteresting appraisals, providing alternatives, views to others and predictions. In line with this, most researchers agree that it is essential to achieve 63 Conversely students who have low interpersonal communication work less hard in learning, less courage in asking questions and less courage in expressing opinions. Students who have low interpersonal communication if they do not change their learning attitudes, the abilities of students will be difficult to develop in obtaining learning outcomes.

Interpersonal communication is very influential on learning outcomes, if high student interpersonal communication can improve learning outcomes, the findings of this study suggest there is an influence of interpersonal communication in improving learning outcomes. For high interpersonal communication the average score of civic student learning outcomes of Akper Sari Mutiara Medan City XKIT $=25.93$ is better than the average score of civic learning outcomes of Akper Sari Mutiara students of Medan who have low interpersonal communication X KIR $=21.09$. High interpersonal communication will make it easier for students to accept or understand the subject matter.

The third hypothesis testing results state that there is an interaction between participatory learning of interpersonal communication in influencing student Civics learning outcomes. Or in other words, the level of student communication has a different effect on Civics learning outcomes regardless of the learning strategies used, students who have low interpersonal communication to do participatory learning. Through participatory learning students are expected to obtain a more complete and detailed picture which in turn is expected to grow in communication for further development.

Thus it can be concluded that participatory learning was created to help students in overcoming learning difficulties and improve communication. Likewise students who have high and low interpersonal communication greatly affect the learning outcomes of Civics. In this case explained interpersonal communication is the result of learning can be learned through the teaching and learning process. Interpersonal communication is the basis for the delivery of learning information that reflects thinking, solving problems and producing something new is a complex activity and is closely related to each other, a problem generally cannot be solved without thinking, and many problems require new solutions for people or groups. Instead of producing something new for someone, creating something that includes problem solving information. Students who have high interpersonal communication tend to be more active in learning activities, conversely students who have low communication are difficult to make decisions let alone in developing correct concepts. 


\section{Conclusion}

From the description of the results of the study presented, conclusions can be drawn: Individual participatory learning strategies do not provide better Civics learning outcomes when compared to participatory learning strategies. Students who have high interpersonal communication get better civic learning outcomes compared to students who have low interpersonal communication.

There is an interaction between participatory learning strategies and student communication in influencing Semester I especially student civic learning outcomes, which has high interpersonal communication and individual participatory learning strategies are as effective as group participatory learning strategies, but for students who have low communication it turns out that participatory learning strategies are more group effectively used to improve Civics learning outcomes compared to individual participatory learning strategies.

\section{References}

Arikunto, Suharsimi. (1999). Dasar-dasar Evaluasi Pendidikan. Jakarta : Bina Aksara. Dunne Elisabeth, (1999), The Learning Society International Perspectives on core skills in higher education, Brithish Library.

Djiwandono, I, (2002). Psikologi Belajar . Jakarta : Rajawali Pers.

Fajar, Murhaeni (2008) Ilmu Komunikasi Tiori \& Praktik, Jakarta : Graha Ilmu Fudyartanto, RBS (2002) Psikologi pendidikan dengan pendekatan baru. Yogyakarta: Global Pustaka Utama.

Gagne, R.M (1985). The Condition of Learning and Theory of Instruction (4th Edition).New York: Hott Rinehart and Winston.

Gardne, Roy, Jo Cairns and Denis Lawton, (2000), Education for values: Morals, Ethics and Citizenship in Contemporary Teaching, Brithish Library.

Gulo (2002), Strategi belajar Mengajar. Jakarta : Raja Grafindo Persada.

Gredler, M.E.B, (1994). Belajar Membelajarkan .Alih Bahasa Munandir. Jakarta : Raja Grafindo Persada.

Hasan, Chakijah. (1994). Dimensi-Dimensi Psikologi Pendidikan. Surabaya: Al Ikhlas.

Hamalik, Oemar. (2001). Perencanaan Pengajaran Berdasarkan Pendekatan Sistim . Jakarta: Bumi Aksara.

Hasan. I. M. (2003), Pokok-Pokok Materi Pendidikan Pancasila. Jakarta : Raja Grafindo Persada.

Melian, S dan Marzuki, S (2003), Pendidikan Kewarganegaraan. Jakarta : Gramedia Purtaka Utama.

Moedjiono dan Hasibuan, J,J, (2000), Proses Belajar Mengajar . Bandung: Remaja Roda Karya.

Rasien. (2020). The Effect of Blended Learning Strategy and Creative Thinking of Students on the Results of Learning Information and Communication Technology by Controlling Prior Knowledge. Budapest International Research and Critics in Linguistics and Education (BirLE) Journal. P. 879-893.

Saragih, K., and Mardianto. (2019). Relationship between Teacher Professional Performance and Discipline of Workers withTeacher Professionalism in Madrasah Tsanawiyah in Pematangsiantar City. Britain International of Linguistics, Arts and Education (BIoLAE) Journal; 1(2): 77-84. 